\title{
Germplasm Characterization and Flowering, Fruiting Nature of Burmese Grape (Baccaurea Sapida Muell. Arg.) - a Potential Fruit Crop for Nutrition in Rural South East Asia
}

NILESH BHOWMICK ( $\square$ nileshbhowmick@gmail.com )

Uttar Banga Krishi Viswavidyalaya https://orcid.org/0000-0002-9795-3160

Saurabh Pradhan

Uttar Banga Krishi Viswavidyalaya

\section{Research Article}

Keywords: Burmese grape, Germplasm, Characterization, Flowering, Fruiting

Posted Date: May 7th, 2021

DOl: https://doi.org/10.21203/rs.3.rs-477266/v1

License: (c) (i) This work is licensed under a Creative Commons Attribution 4.0 International License.

Read Full License 


\section{Abstract}

Burmese grape (Baccaurea sapida Muell. Arg.) belongs to the family Euphorbiaceae, is a minor underexploited fruit crop grown wild as well as under cultivation in Nepal, India, Myanmar, Bangladesh, China, Thailand, for fresh consumption. It is a dioecious plant and reported to have an excellent nutritive value, but mainly grown in homestead condition mostly in neglected ways without fullest utilization of its potentiality. The present study was aimed to understand and first time characterize the germplasm nature, and details of flowering and fruiting system of Burmese grape. The experiment showed that, tree growth habit and crown shape of all the accessions surveyed were semi erect and irregular, respectively. The flower bud differentiation in male and female accessions started during the mid February and anthesis occurred from mid March for both male and female accessions. The colour of the male flowers varied from yellow to green yellow shades while the colour of the female flowers varied from yellow to yellow green and green yellow shades. Significant variation of leaf area, number of flowers per panicle, length and diameter of inflorescence, fruit length, breadth, weight etc. were observed. The variation present on fruit length $(2.81 \mathrm{~cm}$ to $3.80 \mathrm{~cm})$, fruit weight $(12.25 \mathrm{~g}$ to $22.95 \mathrm{~g})$, pulp percentage $(49.82 \%$ to $65.33 \%)$, total soluble solids $\left(9.00^{\circ}\right.$ to $\left.13.10^{\circ} \mathrm{Brix}\right)$, tritable acidity $(0.73 \mathrm{mg}$ to $1.28 \mathrm{mg} / 100 \mathrm{~g}$ fruit pulp) and ascorbic acid content ranged from $(23.18 \mathrm{mg}$ to $57.80 \mathrm{mg} / 100 \mathrm{~g}$ fruit pulp) suggest suitable selection method for identification of promising Burmese grape genotypes.

\section{Introduction}

Baccaurea is a genus of flowering plants belonging to the family Euphorbiaceae. Burmese grape (Baccaurea sapida) is one of the popular underutilized fruit plants native to South East Asian region and growing wild as well as under cultivation in Nepal, India, Myanmar, Bangladesh, South China, Indo- China, Thailand, the Andaman Island and Peninsular Malaysia. The generic name is derived from Latin 'Baccaurea' referring to its golden yellow colour of the fruits (Chakrabarty and Gangopadhayay 1997). This fruit crop is grown in forest, semi-forest, forest fringed areas and also domesticated in homestead condition. In India it is grown as a minor underexploited fruit crop under the sub-Himalayan Terai region of West Bengal and north east India, Andaman Island for fresh local consumption. It is a slow growing, evergreen, dioecious, short to medium height, shade loving plant species, and fruits are acidic in taste (Bhowmick, 2009). Apart from fresh consumption the fruits can be used for making wine, juice and jams. The haploid chromosome no. of B. sapida is reported to be 13 (Mehra and Hans, 1969). It flowers during summer months and fruits are matured during rainy season. The edible portion is aril (3-4 in no. per fruit) and is covered by leathery rind. The tree show mild bienniality in cropping pattern (Pal et. al., 2008). It is a hardy pant, and grown as neglected crop without much more care even in forest fringed area, road side plantation. The Burmese have plentiful nutrients as reflected in world literature. Though the crop is reported to contain good nutritional properties like ascorbic acid, antioxidant capacity, proteins, minerals like calcium, phosphorous, and seeds having antifungal activity, however, its potentiality for alleviation of rural malnutrition particularly in south east Asiatic region (area of its occurrence) has yet not tapped properly, which may be explored. Fruits of Burmese grape contain 5.5 percent protein, $178 \mathrm{mg}$ vitamin C, 
$169 \mathrm{mg}$ calcium, $137 \mathrm{mg}$ potassium, $177 \mathrm{mg}$ phosphorous, and $100 \mathrm{mg}$ iron per $100 \mathrm{~g}$ of fruit pulp (Kermasha et al., 1987) indicating its nutritive value for the rural areas. In spite of the potentiality, the Burmese grape is grown as little care on homestead condition raised by seeds creating variability in genotypes. However, very little systematic information is available in world literature regarding the characterization of germplasms and flowering, fruiting behaviour of this crop. The present attempt was the first report to characterize the genotypes of the crop and systematic documentation of flowering time, flowering duration, number of flowers per panicle, initial fruit set per panicle, ultimate fruit retention, yield, physico-chemical properties of fruit.

\section{Materials And Methods}

Burmese grape (Baccaurea sapida Muell.Arg) is dioecious and highly heterozygous in nature as well as no information is available regarding the variety/cultivars/types of the crop in worldwide. Keeping this point in consideration it has assumed that a variation among the population is present and each germplasm was treated as single accession during this experiment. During the study a survey was made on various home gardens of sub-Himalayan Terai region of West Bengal by making a questionnaire and after the whole survey, twenty numbers of female plants (accession) and fifteen numbers of male plants (accession) were selected as superior accessions based on plant vigour, bearing habit, size, shape and colour of fruits, taste, appearance for further analysis during the experiment to characterize the flowering and fruiting behaviour of germplasm as well as to know the variability among the selected plants. The germplasm with four replications for each observation were analyzed using one way classified data. Analysis of variance (one way classified data) for each parameter was performed using ProcGlm of Statistical analysis System (SAS) Software (Version 9.3). Means separations for different accessions under different parameter were performed using Tukey's Studentized Range (HSD) test $(P \leq 0.05)$ (Tukey, 1953). The parameters like tree growth habit, branching pattern, crown shape, and trunk surface were recorded following the Litchi Descriptor (as the standard descriptor is not available and the canopy size is similar with litchi) of International Plant Genetic Research Institute (IPGRI), Rome, Italy. The colour of different plant parts were recorded with the help of Royal Horticulture Society Colour Chart (fifth edition). Different bio-chemical properties of fruit were recorded following the methods described by Ranganna (1977).

\section{Results}

After the experiment conducted on surveyed population of Burmese grape it was found that the tree growth habit was varied from semi erect to spreading, crown shape of all accession were irregular, branching pattern was erect or irregular or horizontal and trunk surface was rough. Leaf blade shape was elliptic, leaflet base shape was cuneate. It was also observed that the type of phyllotaxy was alternate, leaf apex shape varied from acute to acuminate and the bearing habit of Burmese grape was cauliflory (flowers and fruits are directly coming from the stem). The present investigation revealed that there was significant variation among different Burmese grape accessions from various parameters observed under 
this study. The height of the male and female accessions varied from 2.59-7.39 m and 4.92-13.06 m respectively. While the length of leaf blade ranged between $16.50 \mathrm{~cm}$ (ACC-12) to $19.58 \mathrm{~cm}$ (ACC-5) and $18.15 \mathrm{~cm}$ (ACC-10) to $25.30 \mathrm{~cm}$ (ACC-19) in male and female germplasms, respectively. The breadth of leaf blade varied from $5.00 \mathrm{~cm}$ (ACC-9) to $6.78 \mathrm{~cm}$ (ACC-10) in male and $6.28 \mathrm{~cm}$ (ACC-15) to $9.61 \mathrm{~cm}$ (ACC-2) in female germplasms, respectively. Similarly, the leaf area of male and female Burmese grape germplasms ranged from $16.94 \mathrm{~cm}^{2}$ (ACC-8) to $19.66 \mathrm{~cm}^{2}$ (ACC-3) and $15.23 \mathrm{~cm}^{2}$ (ACC-8) to $20.12 \mathrm{~cm}^{2}$ (ACC-4), respectively. The colour of the upper side of the leaves in both male and female accessions ranged from G 137 A - G 141B shade to G N137 A to G 141 A shades of Royal Horticulture Society colour chart (5th edition). The colour of the male flowers varied from yellow to green yellow shades while, the colour of female flowers varied from yellow to yellow green and green yellow shades of Royal Horticulture Society colour chart (5th edition). The flower bud differentiation of male and female germplasms were started from first to mid week of February while the emergence of inflorescence was started from mid to last week of February. The anthesis occurred between first to mid week of March for both the mal and female accessions surveyed showed synchronization of flowering leading to good fruit set. The number of sepals and petals were 4-5 and 1 , in both male and female germplasms, respectively. The flowering duration varied significantly among the germplasms surveyed. The duration of flowering in male accessions varied from 5 days (ACC-4) to 7.5 days (ACC- 1 ) while in female accessions it was ranged from 6.50 days (ACC-10 and 11) to 9.25 days (ACC-4). The number of flower per panicle in male and female germplasms ranged from 38.00 (ACC-12) to 63.00 (ACC-11) and 24.50 (ACC-13) to 31.50(ACC-7) respectively. The length and diameter of male inflorescence varied from $60.42 \mathrm{~mm}$ (ACC-5) to $117.99 \mathrm{~mm}$ (ACC-14) and 1.42mm (ACC-8) to $1.91 \mathrm{~mm}$ (ACC-2), respectively. Similarly, the length and diameter of female inflorescence varied from $67.90 \mathrm{~mm}$ (ACC-16) to $141.48 \mathrm{~mm}$ (ACC-15) and $1.78 \mathrm{~mm}$ (ACC-1) to $2.54 \mathrm{~mm}$ (ACC-16), respectively. The fruit set in different germplasms were observed during the mid to last week of March. The shape of the fruit was oval or round.. The time taken for aril formation after fruit set and maturity of fruits varied from 42 to 51 days and 94.5 to 105.25 days respectively. The colour of the aril during maturity varied from white (W N155 A) to grayish white (W NN155 A), while the colour of ripe fruits varied from yellow to yellow orange groups ( $Y 13$ A to YO 14, 15 B and $C$ ) of Royal Horticulture Society colour chart (5th edition). Experimental results showed that the initial fruit set per panicle in Burmese grape ranged from 20.00 (ACC-16) to 25.25 (ACC-9). Similarly the initial fruit set percentage ranged from $69.90 \%$ (ACC-16) to $89.47 \%$ (ACC-10). However, it was experienced different phases of fruit drop during the course of growth and development phases and finally the fruit retention percent was ranged from $20.40 \%$ (ACC-18) to $38.72 \%$ (ACC-14). The number of fruits at harvest per panicle was maximum (8.50) in ACC-10 and minimum (4.25) in ACC-18 respectively. The number of fruits harvested ranged from 567 to 4745 . Similarly, yield per tree ranged from $9.97 \mathrm{~kg}$ (ACC-12) to $85.36 \mathrm{~kg}$ (ACC-14). Experimental results show that the fruit length ranged between $2.81 \mathrm{~cm}$ (ACC-3) to $3.80 \mathrm{~cm}$ (ACC-9). Similarly, the fruit breadth ranged from $1.39 \mathrm{~cm}$ (ACC-15) to $3.04 \mathrm{~cm}$ (ACC-20). The fruit weight varied from $12.25 \mathrm{~g}$ (ACC-8) to $22.95 \mathrm{~g}$ (ACC-3). Similarly peel weight was highest in ACC-3 (9.03g) and lowest in ACC-8 (4.04g). Similarly, the maximum (65.33\%) and minimum (49.82\%) pulp percentage was observed in ACC-18 and in ACC-17 respectively. It is evident from the study that the total soluble solids was maximum in ACC-2 $\left(13.10^{\circ} \mathrm{Brix}\right)$ and minimum in ACC-12 $\left(9.00^{\circ} \mathrm{Brix}\right)$. Similarly, the total sugar was 
highest $(7.22 \mathrm{mg} / 100 \mathrm{~g}$ pulp) and lowest $(4.84 \mathrm{mg} / 100 \mathrm{~g}$ pulp) in ACC- 13 and in ACC-2 respectively. Reducing sugar was found to be highest $(6.45 \mathrm{mg} / 100 \mathrm{~g}$ pulp) and lowest $(3.99 \mathrm{mg} / 100 \mathrm{~g}$ pulp) in ACC-14 and ACC-20 respectively. While, the non-reducing sugar was highest $(2.91 \mathrm{mg} / 100 \mathrm{~g}$ pulp) and lowest ( $0.08 \mathrm{mg} / 100 \mathrm{~g}$ pulp) in ACC-13 and ACC-16 respectively, while acidity and Vitamin C was maximum $(1.28 \mathrm{mg} / 100 \mathrm{~g}$ pulp, $57.80 \mathrm{mg} / 100 \mathrm{~g}$ pulp) and minimum $(0.73 \mathrm{mg} / 100 \mathrm{~g}$ pulp, $23.18 \mathrm{mg} / 100 \mathrm{~g}$ pulp) in ACC-17, ACC-2 and ACC-16, ACC-4 respectively.

\section{Discussion}

The present investigation revealed that, there was significant variation among different Burmese grape accessions. The variation of plant height was observed from 2.59-7.39m and 4.92 to $13.06 \mathrm{~m}$, respectively in male and female germplasms surveyed. Similar observations of variation of plant height of 5-25m were also reported by previous workers (Abdullah et.al.,2005 Anon., 2012; Chakrabarty and Gangopadhyay, 1997) from different parts of world. The variation presence in leaf colour, leaf sizes revealed from the present study confirms the differences among the germplasms. The previous workers also reported that the leaves of Burmese grape were simple, alternatively arranged with petiole and oblong or elliptic in shape (Anon., 2012; Chakrabarty and Gangopadhyay, 1997). Anon. (2012) reported that the inflorescence is tomentose and appears on branches and the length of inflorescences of the Burmese grape is similar with the present experiment and the variation of number of flowers present in a panicle may be due to the genetic differences of the germplasms surveyed. Time of flowering observed in this investigation is with the same line as reported by Bhowmick (2009) during March- April. Chakraborty and Gangopadhyay (1997) reported that the flowers are clauiflorous in nature and are 10 to $40 \mathrm{~cm}$ long. The variation of flowering duration of male and female germplasms was noted in the present investigation and it was also observed by Sundriyal and Sundriyal (2004). The high fruit set percentage may be due to the synchronization of anthsis of male and female flowers as well as abundance of pollinating agent. The shape of the fruit was oval or round and the aril colour during maturity varied from white to grayish white, while the colour of ripe fruits varied from yellow to yellow orange groups of Royal Horticulture Society colour chart (5th edition). Bhowmick, (2009) also observed that the fruits were roundish to oval and yellow to yellowish brown in colour when matured. The findings regarding germplasm variation showed that the fruits of Baccaurea were sub-globose, ovoid, ellipsoid or obovoid in shape and are 15-30 mm long and 15 to $25 \mathrm{~mm}$ broad are having similar trends reported by Chakraborty and Gangopadhyay (1997). In a study, Bhowmick (2009) reported that the colour of the Burmese grape fruits is yellow or yellowish brown at ripening. The colour variation of different fruit crops due to germplasm variability was also observed by several scientists (Dhillon and Dhillon, 2008; Shyamali et al 2009). The highest yield in ACC- 14 may be due to highest fruit retention percent (38.72\%); as well as high number of fruits at harvest. The variation of fruit physio-chemical properties, yield parameters on different germplasm confirms the differences of germplasms which may be due to highly heterozygous in nature of Burmese grape in the present experimental areas. This variation is also supported by the earlier workers in different other fruit crops (Sanyal and Maity,1989; Sundriyal and Sundriyal,2001; Anila 
and Radha,2003; Dabral and Misra, 2007; Babu et al., 2007; Pal et al., 2008; Dhillon and Dhillon, 2008; Rekha et al., 2011).

\section{Declarations}

Funding: Funding was sponsored by the Uttar Banga Krishi Viswavidyalaya

Conflicts of Interests/Competing Interest: No conflicts of interest as associates

Availability of data/material: Yes

Code availability: Not applicable

Ethics approval: No ethical approval is needed

Consent to publication: Yes

\section{Acknowledgement:}

Authors are thankful to the Uttar Banga Krishi Viswavidyalaya for providing the fund and facility for conducting the experiment and there is no conflict of interst for this research paper

\section{References}

1. Abdullah ATM, Hossain MA, Bhuiyan MK (2005) Propagation of latkan (Baccaurea sapida Muell. Arg.) by mature stem cutting. Research Journal of Agriculture Biological Sciences 1(2):129-134

2. Anila R, Radha T (2003) Physico-chemical analysis of mango varieties under Kerala conditions. Journal of Tropical Agriculture 41:20-22

3. Anonymous (2012) http://www.fao.org/, accessed on 26 Jan, 2012

4. Babu KD, Patel RK, Yadav DS (2007) Comparative evaluation of guava selections under north eastern region of India. Acta Hort 735:99-103

5. Bhowmick N (2009) Some lesser known minor fruits of northern parts of West Bengal. Acta Hort 890:61-64

6. Chakrabarty T, Gangopadhyay M (1997) The genus Baccaurea (Euphorbiaceae) in the Indian subcontinent. Journal of Economic Taxonomic Botany 21:525-534

7. Dhillon BS, Dhillon WS (2008) Evaluation of hard pear germplasm for fruit bearing and quality attributes. Indian Journal of Horticulture 65(4):389-392

8. Kermesha S, Barthakur NN, Mohan NK, Arnold NP (1987) Chemical composition and proposed use of two semiwild tropical fruits. Fruit Chemistry 26(4):253-259

9. Mehra PN, Hansk AS (1969) In IOPB Chromosome no. report XXI. Taxon 18:310-318 
10. Pal RK, Bhowmick N, Suresh CP (2008) Latka (Baccaurea sapida. Muell. Arg)-an under exploited minor fruit crop of West Bengal, Abstracted in 3rd Indian Horticulture Congress, New R\&D Initiatives in Horticulture for Accelerated Growth and Prosperity, November 6-9, 2008 held at OUAT, Bhubaneswar, Organized by Horticultural Society of India, p. 325

11. Ranganna S (1977) Manual of Analysis of Fruit and Vegetable Products. Tata McGraw-Hill, New York

12. Rekha A, Dinesh MR, Venugopalan R, Murthy BNS (2011) Genetic correlation and cluster analysis in sapota (Manilkara zapota). Journal of Horticultural Sciences 6(2):101-104

13. Sanyal D, Maity SC (1989) Studies on nature of fruit drop and its relation with fruit growth in some mango varieties. Progressive Horticulture 21(3-4):300-304

14. Sharma D, Sahu KR, Singh J (2009) Studies on flowering behaviour in cashew. Indian Journal of Horticulture 66(4):429-432

15. Shyamali GGV, Dhillon WS (2009) Fruit development studies in Asian soft pear. Indian Journal of Horticulture 66(1):43-47

16. Singh S, Singh AK, Joshi HK (2008) Genetic variability for floral traits and yield attributes in tamarind. Indian Journal of Horticulture 65(3):328-331

17. Sundriyal M, Sundriyal RC (2004) Phenology, fruit yield, and future prospects of some prominent wild edible plant species of the Sikkim Himalaya, India. Journal of Ethnobiology 24(1):113-138

18. Sundriyal M, Sundriyal RC (2001) Wild edible plants of the Sikkim Himalaya: Nutritive values of selected species. Econ Bot 55(3):377-390

\section{Tables}

Due to technical limitations, table 1 to 4 is only available as a download in the Supplemental Files section.

\section{Supplementary Files}

This is a list of supplementary files associated with this preprint. Click to download.

- Tables.docx 